\title{
Protected Areas, People and Tourism: Political Ecology of Conservation in Nepal
}

\author{
Rajan P. Paudel
}

National Trust for Nature Conservation, Nepal

Corresponding author: rajanpoudel093@gmail.com

\begin{abstract}
While Protected Area based Tourism (PAT) has become a global phenomenon, its social, economic and environmental implications are also widening. Almost half of the entire tourists coming to Nepal visit protected areas (PAs). The country has embraced this as an opportunity for conservation, poverty reduction and economic development. However, only limited groups, often outsiders or elites, are reported to reap benefits of PAT whilst poor and marginalized groups struggle for both rights and benefits. Further, the distribution of tourist as well as the revenue generated is not even across different PAs. Policy and legal ambience are partly muddled with numerous approaches for resource management. However, recent 'paradigm shift' in the management and governance of PAs offers optimism to address social, economic and environmental anomalies. In the pretext of limited rigorous site specific studies and complexities to measure trade-offs between problems and gains, this article stresses on transformation in PA governance so as to realize full and equitable sharing of benefits from PAT.
\end{abstract}

Key words: Cost and benefits, local community, resource, tourism, Tharu

\section{INTRODUCTION}

Protected Area based Tourism (PAT), an important manifestation of nature-society relationship, has been growing over time and space. Establishment of protected areas (PAs) is now seen as a cornerstone of global resource management (Watson et al. 2014; Meir et al. 2004; Kareiva and Marvier 2007). Over the last three decades, there has been exponential growth in PAs networks particularly in developing countries with rich biodiversity (Treves et al. 2005). PAs in Nepal have grown by many folds between 1973 and 2010 from mere 4376 Sq. $\mathrm{km}$ to $34186 \mathrm{Sq} . \mathrm{km}$ in area (See Figure 1), currently occupying 23.23 per cent of total land area of Nepal which is one of the highest in South Asia (GoN/MoFSC 2014). Vast network of PAs (Figure 2) has tried to incorporate the cultural and biological diversity in the socio-ecological landscape of Nepal where local people's activities are intertwined with nature. Studies have highlighted the mutual interdependencies between tourism, biodiversity conservation and local livelihoods (see Nyaupane and Poudel 2014). Though these PAs have faced challenges from internal and external threats (CBD 2008), it is generally said that PAs in Nepal have been a success story in both conservation and economic development of local communities residing around it. 


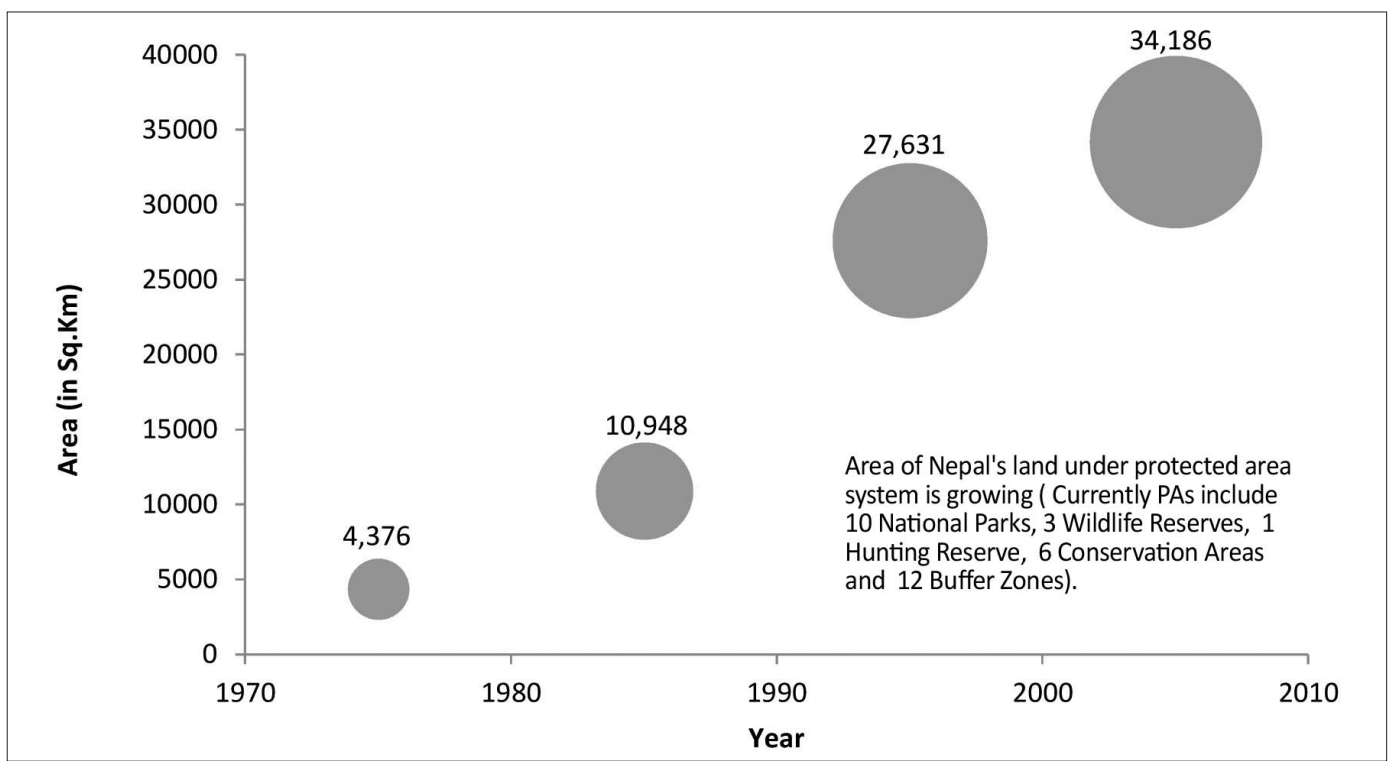

Figure 1: Area of Land under Protected Area System in Nepal in the Last Four Decades (1971-1980s,1981-1990,1991-2000 and 2001-2010 A.D)

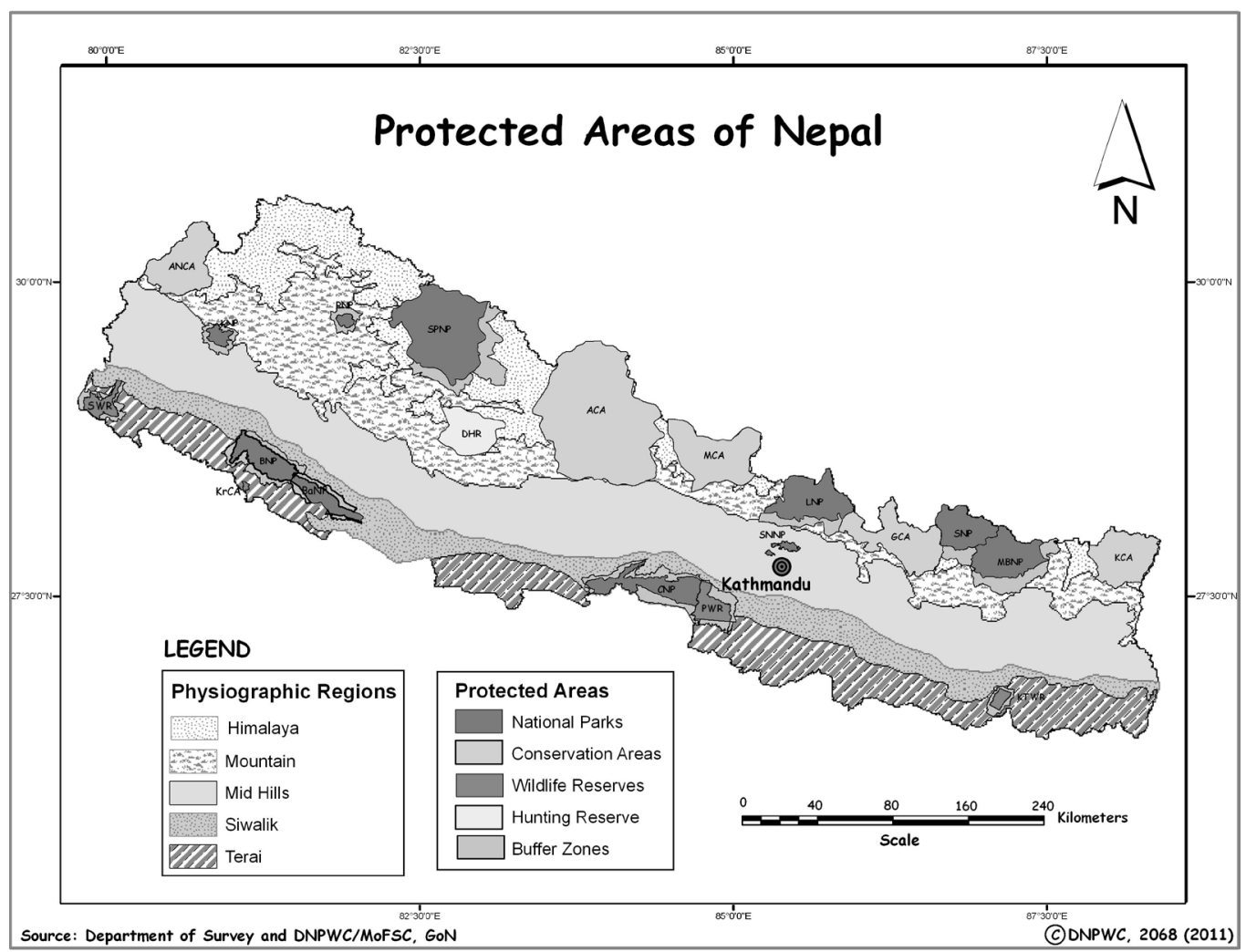

Figure 2: Protected Area Network in Nepal 
While PAs are associated with the goal of conservation along with capitalizing benefits and opportunities of tourism, it is important to acknowledge the social impacts of PAs (CBD 2008). In several instances, PAs, in Nepal and worldwide, have been established on the ancestral territories mainly those of indigenous peoples (Stevens 2013) in which they had historical interactions, connections and resource management practices. Landscapes conserved by indigneous peoples and local communites are rich in culture and nature, and also serve as an important attraction for tourist experiences. Formal conservation policies and programmes of the state, for instance creation of PAs in these landscapes, have inadequate consideration of practices of biodiversity conservation by local populations (Jana and Paudel 2010) and have rather disrupted the existing local social-nature relationships and interactions. Most indigenous communities had to face negative impacts as a result of the creation of PAs in and around their ancestral territories (Fernández and Martin 2007).

The involvement of local population in PA governance and management is now increasingly seen as crucial in conservation of biodiversity. This paradigm shift in the theory and practice of PA management and governance happened notably, since the IVth World Parks Congress 2003 (Bajracharya and Dahal 2008). Concurrently, the mission of PAs has also expanded from mere conservation to achieve diverse objectives including socioeconomic enhancement and human welfare (Watson et al. 2014; Treves et al. 2005).

PAs have become more important, yet remain threatened as the world population grows and the demand for natural resources increase (CBD 2008). However, many PAs lack the capacity to address resource management challenges (Rands et al. 2010), while others remain mostly paper parks (Brandon 1998; Carey et al. 2000). Strictly PAs can result in major livelihood costs and cause conflict between local communities and PA management while allowing sustainable use of forest resources can provide tangible benefits (Coad et al. 2008). Tourism in PAs, on one hand promotes acculturation in wake of accumulation of restaurants and tourist while on the other hand, it might also serve in the diffusion of world cultures (Pandey et al. 1995). Discrepancy also exists in the distribution of benefits as a result of park establishments. While residents and those participating strongly in tourism might recognize the benefits but the villages that are distant from the main tourist entry points to the park and individuals having lower level of participation in tourism recognize few benefits (Spiteri and Nepal 2008). Majority of the local people perceive that PA tourism has addressed their livelihood needs (Karanth and Nepal 2011).

Despite criticisms on the impacts of PA management and conservation policies, tourism, when properly managed and directed, can contribute to biodiversity conservation and poverty reduction, both directly by capitalizing on biodiversity assets and indirectly by reducing the vulnerability of the poor to environmental degradation through biodiversity conservation (UNEP 2003; Kruger 2005). In the vast majority of cases, tourism is seen as an integral component of PA management. Global trends also suggest that countries with expansive PA networks have the capacity to draw large number of tourists to these areas (UNEP 2003). It is estimated that around 8 billion tourists 
visit $\mathrm{PAs}$ like national parks and natural reserves every year, generating US\$ 600 billion in revenues, which is way above the US\$ 10 billion required for safeguarding these sites (Balmford et al. 2015). In addition, PAs also sustain livelihoods of local communities through direct and indirect employment opportunities. In the context of Nepal, tourism contributes to more than four per cent of the Gross Domestic Product (GDP) of the country (WTTC 2015; Dharmaratne et al. 2000).

In this paper, firstly, I briefly present how PAs have evolved over time in Nepal and then demonstrate the growing linkages between PAs and tourism. From the political ecology perspective, I then examine the role of tourism in socio-economic enhancement of local communities focusing on the case of indigenous Tharu peoples around the Chitwan National Park (CNP). This perspective underscores the necessity of understanding the relations between society and nature, arguing that social and environmental conditions are complex and inextricably linked (Adams and Hutton 2007). This paper presents a scenario on PAT and its relation with socio-economic context to highlight the issues of PAs and tourism. By deconstructing the existing social-nature relations and interrogating inequalities and inequities of PA benefits, this approach highlights the structures, process and elements that create socioeconomic relations. The aim of the paper is to contribute to the debates on PAs, tourism and their reformation.

\section{METHODS}

The paper draws information from both primary and secondary sources. Data on tourists visiting PAs and the revenue generation were collected from the reports of the Department of National Parks and Wildlife Conservation (DNPWC) and National Trust for Nature Conservation (NTNC). Data on tourists visiting Nepal was collected from the Nepal tourism statistics published by the Ministry of Culture, Tourism and Civil Aviation. Data and analysis on PAs considered here do not include PAs established after 2009 given their short history of establishment and absence of tourism data at the time of the study. Desk-based review of relevant literatures on PAs, tourism and people was conducted. Primary information was gathered through direct field observations at CNP in 2008, 2010 and 2016, Bardiya National Park (BCP) in 2010, and Annapurna Conservation Area (ACA) in 2012, 2013, 2014, and 2016. Reflective approach to learning was considered in this study through integration of reflections from informal consultations with PA managers, rangers, foresters and local populations in and around PAs and tourism entrepreneurs.

\section{EVOLUTION OF PROTECTED AREAS IN NEPAL}

Earliest history of tourism in Nepal can be traced back to the accounts of visits by missionaries, pilgrims and foreign dignitaries, especially members of the British Royal family who were invited by various Nepalese rulers to partake in big game hunting as a great game of diplomacy (Bhandari 2012). Formal conservation began with the passage of national legislation in 1973 which provided strong protection for national parks and wildlife reserves, but denied usufruct rights to rural communities (Heinen and Shrestha 2006). These early parks modeled after the fence 
and fortress parks, exemplified by the Yellowstone National Park, also offered initial impetus for tourism in Nepal.

While tourism activities in the PAs combined with needs of local population increased the demands for park resources, the ban on resource use hindered its fulfillment. This escalated conflicts and led to localized movements linked with the rights of indigenous people in and around the PAs. This was the similar time when master plan on tourism was formulated and tourism act was promulgated in 1979 aimed at regulating travel, trekking and mountaineering, and hotel and restaurant businesses that were flourishing in most of the Himalayan National Parks.

Additionally, there was an increasing international pressure to link PAs with local peoples, communities and sustainable development, particularly after the recommendation of $3^{\text {rd }}$ World Parks Congress in Bali and nationally after the success of community based forest management as a model of resource management. The Government of Nepal heeded to this national and international pressure through gradual involvement in democratic deliberations in PA management. As a result, various structural and managerial reforms have been achieved including concessions on access to park resources particularly for grass to livestock and firewood for households, introduction of Conservation Areas (in 1989), and Buffer Zone concept (in 1994) with the provision of PA revenue sharing. Further, the then king provided patronage for involvement of Non-Governmental Organizations (NGOs) in conservation through establishment of King Mahendra Trust for Nature Conservation, now known as the National Trust for Nature
Conservation - a quasi-governmental organization. There has been an increasing role of International/National NGOs in conservation ever since NTNC has been leading conservation, development and management of tourism in most of the conservation areas.

Different local level institutions such as conservation area management committees and buffer zone management committees represent the local people and ensure their involvement in planning and implementation of different conservation and development activities. However, these committees are largely governed or influenced by park administration as major decisions need approval from central authorities like the Department of National Park and Wildlife Conservation (DNPWC) and NTNC before they can actually be implemented. Despite the success of community based conservation and presence of local institutions, local people are asked to involve in narrow frameworks of participation and the policy space and agenda setting is still dominated by the state agencies, donors and big conservation organizations (Paudel et al. 2012). Thus, the recent paradigm shift in PA management under the aegis of participatory conservation management still has a long road to travel in terms of providing spaces for local people particularly the poor, women and marginalized groups in decisionmaking process and equitable sharing of benefits. As this paradigm shift in the PA governance and management in Nepal is being realized, PAs now have become one of the most prominent platforms for local governance, natural resource and tourism management (ODI 2014). 


\section{PROTECTED AREAS AND TOURISM}

National parks and wildlife reserves were established in 1970s and subsequently in 1980s that propelled tourism in PAs. The boost in tourism was provided by the Conservation Areas (particularly ACA) established in the 1990s that encompasses rich biodiversity mixed with cultural diversity in their natural landscapes. Even a small increase in the funds of these PAs from tourism activities can be expected to increase their ability to protect biodiversity and realize socio-economic sustainability. The most important contribution of PAT is that it offers jobs in the remote rural areas of Nepal where such opportunities from other sectors are very rare (Bajracharya et al. 2007). The main income of PAs today comes through park entry fee levied from national and international visitors and has been supportive towards generating money needed to carry out park management activities.

This trend of tourists visiting PAs has grown stronger in recent decades (Chaudhary 2001), with almost half of tourists coming to Nepal (See Figure 3). Tourist flow that had decreased in early 2000s picked up after mid-2000s that correspond to the end of the 10 years long Maoist insurgency. This rise in the trend on tourists visiting PAs closely corresponds to the revenue generated from it (See Figure 4). However, results from analysis of tourist data and revenue generated show that distribution of tourist as well as revenue generation are not uniform in all PAs. While CNP, Sagarmatha National Park (SNP) and Annapurna Conservation Area (ACA) have been noteworthy in contributing to the overall tourism, others have remained trivial.

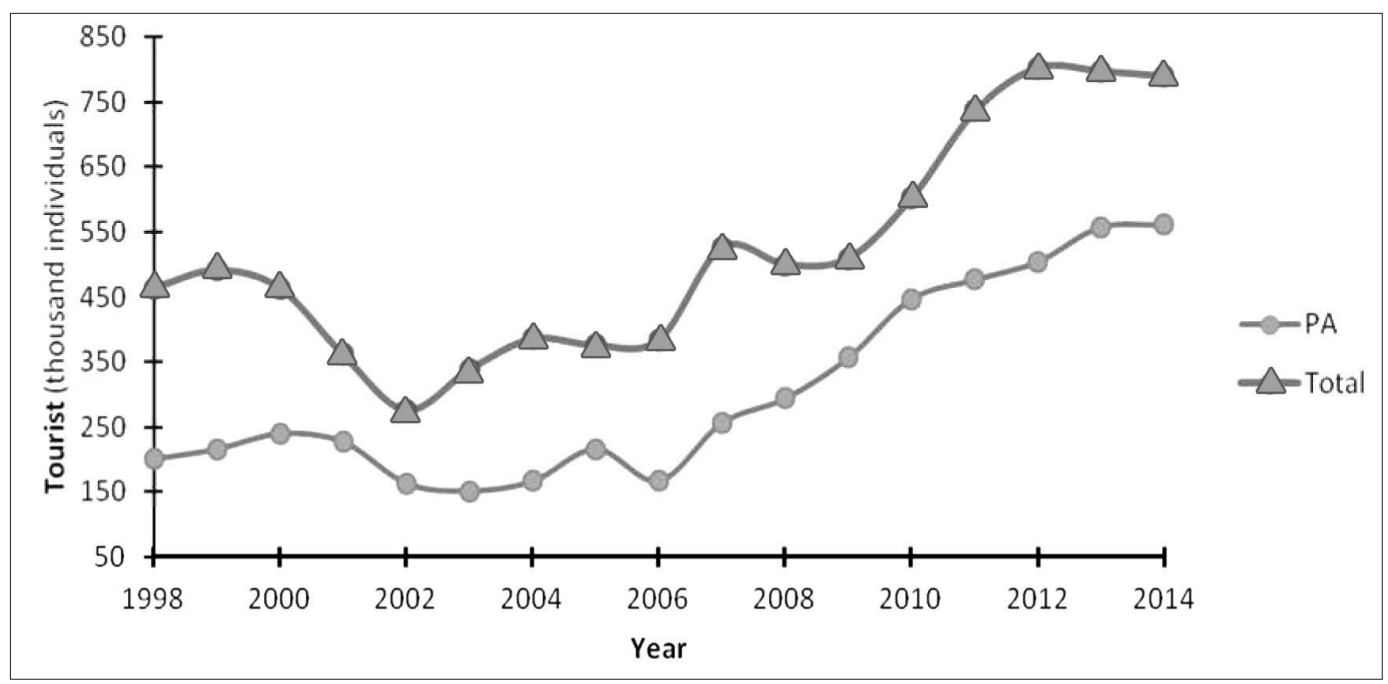

Figure 3: Trend of Tourist in Protected Areas of Nepal 


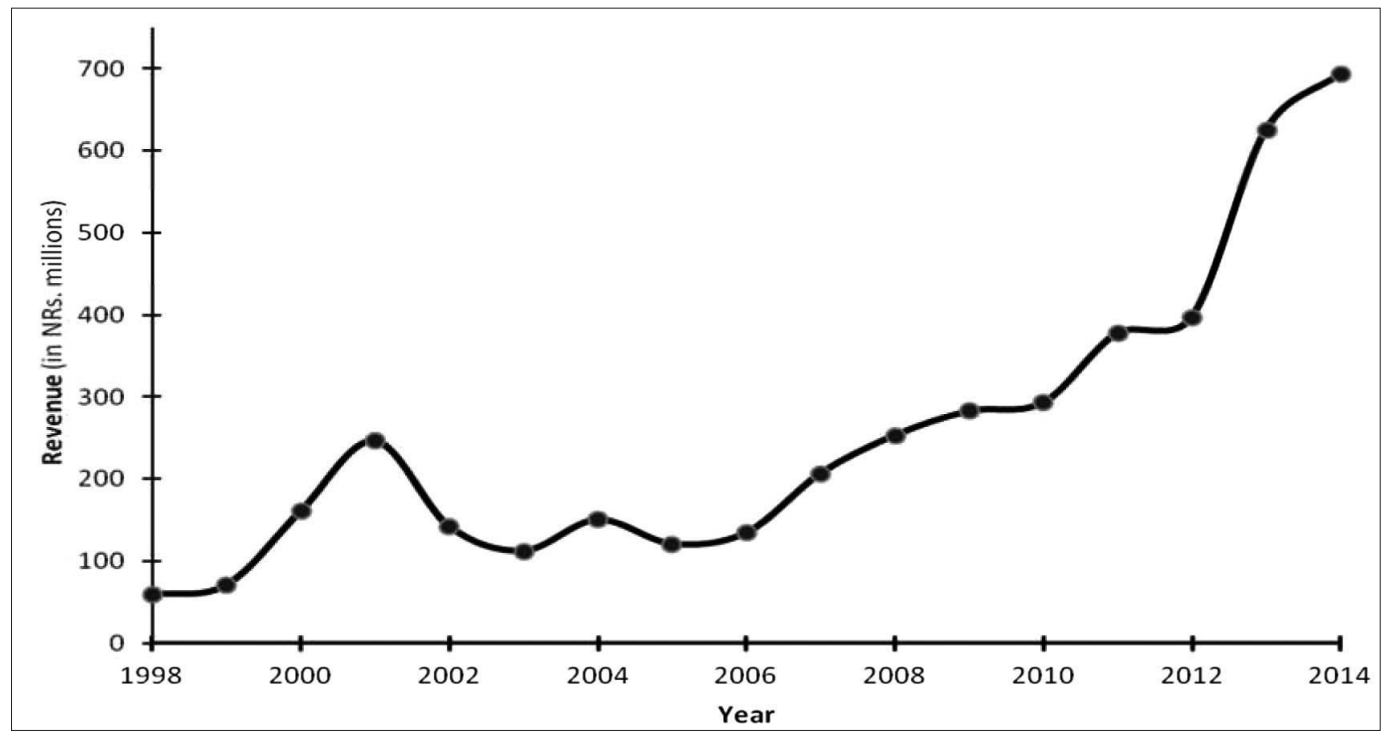

Figure 4: Revenue Generated from PAs in Nepal

Lowland PAs (particularly CNP) are popular for wildlife tourism including activities like elephant riding and jungle walk among others. Likewise, highland PAs (particularly SNP and ACA) present opportunities for mountaineering and trekking. Mid-hill ecosystems remains less represented [currently Shivapuri-Nagarjun National Park (SNNP), Khaptad National Park (KNP) and Dhorpatan Hunting Reserve (DHR)] in current PA system (Shrestha et al. 2010), despite its ecological and cultural richness having larger potential for tourism. The number of tourists to SNNP has not been significant compared to other PAs in the Mountains and Terai. Many hikers, cyclists, bird-watchers, rock-climbers and general public visit the area for short period as the only national park available near Kathmandu valley. In the second tier lie Bardiya and Langtang national parks. Tourist numbers in other PAs in Nepal are negligible where few PAs (KNP, DHR Rara National Park, and Parsa Wildlife Reserve) have not been able to reach a benchmark of hosting a meager total of five thousands foreign tourist even after decades of their establishment. The potential of PAs to attract tourists and thus generate revenue varies across different PAs and thus current contribution of PAT to the local and national economy remains uneven. Studies have also shown that despite opportunities in formal and informal employment, most park-based tourism benefits in countries like Nepal have been rather small and heavily skewed (Nyaupane and Thapa 2004), and seasonal along with strong gender gap (MoCTCA 2014).

Further, increasing the average length of stay of foreign tourists has remained a challenge, which has fluctuated between seven days in 2002 to 13 days in 2004, despite decades of investments in tourist infrastructure like hotels, airports, and the development of diverse adventure sports geared toward tourists. This has pushed Nepalese tourism in a path of unsustainable 'high volume- low value' tourism. In addition, political instability has caused uncertainty for sustained growth in 
tourism (Nepal 2010) and continues to remain a challenge. Such fluctuating trend of tourist and returns from tourism sector increases the risk and uncertainties that might discourage many indigenous people to make significant investment in tourism as their major livelihood option.

\section{SOCIO-ECONOMIC ISSUES IN PROTECTED AREA TOURISM}

The rise in PAT worldwide has resulted in increased levels of stress on parks (Nyaupane and Thapa 2004). Policies and management of PAs have long been criticized as playgrounds for the elite few. The costs of developing tourism in PAs are usually borne by local communities, who are often displaced to make way for parks and associated developments. PAT, therefore, tends to reproduce existing economic inequalities within local communities and wider society (Adams and Hutton 2007).

Establishment of PAs in Nepal has compromised the ability of the local people to depend on sustainable livelihoods. Communities like Malaha (Gondi), 'Sonaha' Majhi and disadvantaged caste groups such as Mukhiya, Sardar, Sada and Mushar living around the lowland PAs face the cost of conservation and struggle constantly against PA management in order to gain fishing concessions, and customary rights to collection of wild fruits and vegetables, grass and fuel-wood (Paudel et al. 2010). Restrictive policies of PAs on one hand have led many members of the poor communities living adjacent to these PAs to forego traditional subsistence activities like fishing, fodder and forage collection for livestock, fuel-wood gathering and other wild edibles while on the other hand the benefits arising from tourism and PAs have not percolated to them. Similar situation exists in several mountain PAs where local indigenous communities like Tamang, Gurung, and Sherpas have had their traditional rights to collect resources restricted. This has resulted in escalated instances of conflicts between park agency and people; studies on this issue have been conducted since the early 1990s (for example, see Sharma 1990; Nepal and Weber 1993; Steven 2013), and even after 25 years, there seems to be no end in sight to these struggles.

PAT has accentuated the inequity between those who have the ability to invest on tourism services like hotels and restaurants, and those who do not have such ability. Though, my observations in and around PAs, particularly ACA, have shown that some of the indigenous communities benefit economically from tourism through involvement in activities like homestay that requires less investments. But in the vast majority of cases, it has put an unnecessary burden on the poor, marginalized, and ethnic communities who have been deprived of access to park resources. Additionally, programs like homestay have the risk of gradually eroding the traditional culture and practices of indigenous people as they are more directly exposed to tourists than the hotel businesses whilst the benefits are relatively very low in comparison to the benefits that the big investors make from their hotel businesses. Many families forgo their traditional agro-forestry and livestock practices in order to involve in tourism business, thus, making them reliant on the latter (UNESCO 1995). This has increased competition in tourism business where many small-scale tourism entrepreneurs are squeezed by outsiders as 
a result of inability to compete by making bigger investments at once as they generate their own capital over time, by starting small and reinvesting profits over several years (Nepal 1997; Ashley et al. 2000). With the exception of the Sherpas in SNP who have been relatively very successful in capitalizing mountaineering and trekking related tourism, and the Gurungs in ACA, local residents in most cases have not been able to realize the benefits of tourism. The following case of Tharu indigenous peoples illustrates ongoing challenges in environmental and social justice associated with PAT.

\section{Chitwan National Park and Impacts on Tharu}

As Vandergeest (2003) argues, development has the potential to cause displacement owing to the push and pull factors. The fate of the Tharu community has been uncertain due to direct interventions of government supported by different agencies at different times (for eg. the resettlement project of the 1960s and the establishment of CNP in 1970s). They have been victims of double repression, one imposed from the hill migrants and the other by limiting their freedom to use the space and resources that they traditionally enjoyed due to the establishment of CNP (Muller-Boker 2000). Most Tharus, who were once the major inhabitants, real users and custodians of the forest in the lowland Terai (Muller-Boker 1999) now represent 6.75 per cent of Nepal's total population (CBS 2002) and approximately 11 per cent of the total population of Chitwan district that is predominantly occupied now by the Brahmins who migrated from the hills (CBS 2014).
Since its establishment, CNP has been at the heights of conservation efforts and a major tourist hotspot. However much of this success has been achieved at the expense of direct and indirect impacts on the well-being of indigenous Tharu peoples. Establishment of CNP has impeded their access to resources such as firewood, fodder, medicinal plants and fishing (Lipton and Bhattarai 2014). It had negative impact on their traditional lifestyles. Restriction on collection of wild foods and medicines influenced the health and culture of Tharus as they are often the only source of nutritional diversification and necessity for religious purposes for many forest dependent poor (CIFOR 2014).

Almost 10,000 inhabitants of Padampur alone, along with many other Tharu settlements were relocated as part of a policy to keep the park "wild" and free from incursions (McLean 1999; MullerBoker 2000). Relocated families received compensation for the land but have less access to opportunities from tourism and other economic activities, and the chances of loss of traditional knowledge and culture are also high as they have to adapt to the changed circumstances (McLean 1999).

My observations and interactions with the local people, Tharus and park staff in the buffer zone suggest that major benefits from tourism have been captured by the hill migrants and outsiders while very little benefits have trickled down to the local Tharu community. Many tourist facilities are owned and operated by citybased entrepreneurs whose motivations may be driven more by profit rather than channeling benefits to the local 
communities. Few of those, making benefits from tourism tend to further invest in places outside of their running businesses mostly in big cities such as Kathmandu and Pokhara (Pandey et al. 1995) thus, limiting opportunities in overall socio-economic development of the local area. The Tharus, whether willingly or unwillingly, have participated in the tourism industry as a survival strategy, working for menial jobs as kitchen helpers, "mahoute" or elephant drivers and caretakers, canoe rowers, jeep drivers, and other similar low-end jobs. A study by Pandit (2012) shows that Tharus were involved in merely 10 per cent of the managerial posts and ownerships in hotels while their involvement in lower ranked positions constituted 75 per cent.

Similarly, the indigenous Tharu culture, which is based on mutual interdependence and respect between human and wildlife, has been commercialized (Pandey et al. 1995) and relegated to odd cultural shows performed in the presence of foreign tourists, the majority of whom are simply unaware of the rich ecological and cultural history of Tharus. The Tharu's ecological niches and culture has been unapologetically exploited by the dominant "hill" group (Pandit 2012), and this exploitation continues in the name of PAT. Even non-Tharu people have adopted Tharu dances that have become a side-job performed on demand at different hotel premises.

\section{DISCUSSION}

PAs are the hotspots and a strong institution for biodiversity conservation, and tourism promotion (Treves et al. 2005; Venter et al. 2014). Trend on expansion of PAs over time and space reflects its establishments as the dominant approach of resource management. However, current revenue generation from PAs shows disparity despite those areas having significant natural and cultural attractions that tourists can experience. The primary reasons for this disparity on revenue from tourism in PAs include lack of proper transportation facilities to these areas, lack of well-developed infrastructure within the parks, and incoherent government policies on distributing tourist flows to less popular PAs. There are discrepancies in the entry fees, which is very nominal according to National Park and Wildlife Conservation Act (1973) where it stipulates Nepalese Rupees (NRs) 10 for Nepali citizens and NRs 250 for foreigners in the national parks, wildlife reserves and hunting reserves managed by government. It further stipulates NRs 200 for South Asian Association for Regional Cooperation (SAARC) nationals and NRs 2000 for tourists from other countries in the conservation areas that is managed by the NTNC. As entry fees are the major source of revenue in PAs, discrepancies and its rate below the willingness to pay by visitors have the potential to cause visitor congestion in easily accessible parks like SNNP and CNP and forgo opportunities for local communities as envisaged by participatory conservation and development including the buffer zone policy (Pandit et al. 2015). A significant amount of revenue is also generated from other activities of the tourist including adventure activities and daily expenses for food and lodging that is not necessarily accounted in PA's earning from tourism.

Establishment of PAs and PAT in particular involves both costs and benefits. Extending PA benefits to small landholders, households that are highly resource-dependent or experiencing 
higher income losses from human-wildlife conflicts, and less educated residents are particularly important to balance costs resulting from living around PAs (Karanth and Nepal 2012). Unequal distribution of costs and benefits depends largely on how these are governed and managed. PAs establishment, however, have compromised the resource use and access rights of many local people depending on the resources and the efforts made to address them, though successful to some extent, have largely been inadequate. The case of marginalization of the Tharu community suggests how PAs establishment and potentials of tourism alone are not enough for the development of indigenous peoples and local communities. In a co-managed model like that of ACA programme, local population still have dominance when it comes to the right to the land, resources and hotel business. For instance many people from Lamjung, Gorkha and Dhading are involved as hotel workers and wage labors in the hotel business run by inhabitants of Manang. Outsiders here are neither allowed to buy lands nor start their own business without marrying the locals. On the contrary, in case of government managed model like that in CNP, indigenous Tharu people were displaced and their right to access and use resources were compromised. State induced resettlement of the hill people resulted in Tharu's minority and marginalized in their own ancestral lands. While, CNP is one of the highest revenue generating park, Tharus living adjacent to the parks have to struggle for livelihoods instead of reaping the benefits from tourism.

The on-going resistance, discontent and conflicts demand a fundamental transformation of the existing power relations, roles and responsibilities of actors in conservation (Paudel et al. 2010). However, as argued by Sunam et al. (2015), civic resistance in PAs have enjoyed limited success as they focus on selective 'low-hanging cherry picking', mostly for political benefits. Such rights based movements have not been able to fully ensure greater economic benefits from tourism for Tharus. Local resistance around PAs in Nepal and recognition of local people issues including development have led to participatory approach in PAs.

Buffer Zone concept as a result of parks and people program provided the rights to buffer zone users to enter and use the forests; but they have no other rights of management, exclusion, or enforcement (Agrawal and Ostrom 2001). It is alleged that most of the buffer zone management committee are largely governed or influenced by park administration and very little voice of the marginalized people are heard. Likewise, although local peoples and communities are responsible for management plan preparation in Conservation Areas, in reality, they are mostly prepared by staff involved with PAs. Even if they are prepared with full people's participation, they must be approved by central authorities like the DNPWC and NTNC before they can actually be implemented. Additionally, the likelihood of participation in community level user groups in the decentralization decision making process in PAs is greater for those who are economically and socially better-off; thus it is important to build institutional mechanisms that encourage poorer and more marginal households (Agrawal and Gupta 2005). Ensuring sustainable conservation and management 
of tourism in PAs will require enhanced cooperation and concrete partnerships among the related government and nongovernment stakeholders; devolution of authority to plan, implement and manage conservation activities to the local communities (Bajracharya and Lama 2008).

Involvement of multiple stakeholders and institutions has also created conflicts of authorities, thus creating confusions and limiting management's effectiveness. For example, the Nepal Army holds the responsibility of Park protection and most of the DNPWC's budget is directed towards maintaining security in and around the park, thus making it a resource constraint institution. Further, DNPWC has no authority to regulate the numbers or activities of tourists and trekkers in the parks, as the Department of Immigration and Tourism in-charge of issuing permits for trekking and mountaineering, most of which takes place within PAs. Jurisdiction or mandates to work outside PAs with the communities who are most negatively affected by the existence of PAs do not lie with DNPWC. A broad need for achieving a win-win policy strategy by attaining a balance / harmony between conservation, development and human welfare through the promotion of participatory interventions have been sought as an alternative to the creation of parks under pure ecological and financial frameworks (Adams and Hutton 2007).

\section{CONCLUSION}

This paper analyzes the linkages between PAs and tourism and further assesses the role of tourism in socioeconomic development of marginalized communities, particularly the Tharus, residing around CNP. The paper draws conclusion that the increasing trend of tourist flow and revenue generation, though not even across different PAs, has provided the economic justification for the management and expansion of PAs for conservation and resource management in Nepal. Despite a paradigm shift in PAs and institutionalization of participatory approaches, local people still remain as clients rather than active agents with rights. Government authorities make final decisions on resource use and tourism regulation. The benefits of tourism in PAs are highly skewed towards the state and more resourceful persons of society, while the poor and indigenous peoples at the margins of hotspots of tourism are in the shadow. The case of CNP and Tharu supports evidences of Tharu marginalization in PAs and tourism (also see Lipton and Bhattarai 2014). The case clearly demonstrates how tourism activities in the area has rather reinforced unequal power relations contributing to the social stratification between hill migrants and Tharus which is in line with the previous findings by Pandit (2012). While the number of tourists and subsequently the revenue generation from PAs is increasing, benefits distribution is not even. Very few benefits have trickled down to the Tharus while the negative impacts on culture is widening. The problem also lies to some extent, as Brandon (1998) suggests, in our unfair expectation from PAs to cure all the structural problems such as poverty, unequal land and resource allocation, corruption, injustice and market failure. Conservation and marginalization of local people and other problems faced by those living in the vicinity of PAs has to be understood as well in the historical context, within the wider political structure, socioeconomic developments and the extension 
of capitalism to the global periphery (McNeely and Miller 1984; Emerton 2001; O'Riordan and Stoll- Kleeman 2002; Igoe 2006). Robust studies incorporating the political ecologies of PAs and tourism management is imperative to explore the social, economic, and environmental dimensions, benefits and equities in relation to indigenous peoples and local communities while also actualizing tourism potentials and financial sustainability of PAs.

\section{REFERENCES}

Adams, W.M. and Hutton, J. 2007. People,Parks and Poverty: Political Ecology and Biodiversity Conservation. Conservation and Society, 5(2): 147-183.

Agrawal,A.andGupta,K.2005.Decentralization and Participation: the Governance of Common Pool Resources in Nepal's Terai. World development, 33(7):1101-1114.

Agrawal, A. and Ostrom, E. 2001. Collective Action,PropertyRights, andDecentralization in Resource Use in India and Nepal. Politics and Society, 485-514.

Ashley, C., Boyd, C. and Goodwin, H. 2000. Pro-Poor Tourism: Putting Poverty at the Heart of the Tourism Agenda. Natural Resource Perspectives, Number 51, Overseas Development Institute, March 2000.

Bajracharya, S. B. and Dahal, N. 2008. Shifting Paradigms in Protected Area Management. Kathmandu: National Trust for Nature Conservation.

Bajracharya, S.B. and Lama, A.K. 2008. Linking Tourism To Biodiversity Conservation: A Paradigm Shift in Protected Area Management. In: S. B. Bajracharya and N. Dahal, Shifting Paradigms in Protected Area Management (pp. 107-118). Kathmandu: National Trust for Nature Conservation.

Bajracharya, S.B., Gurung, G. and Basnet, K. 2007. Learning from Community Participation in Conservation Area Mangement. Journal of Forest and Livelihood, 6(2): 54-66.

Balmford, A., Green, J., Anderson, M., Beresford, J., Huang, C., Naidoo, R., Walpole, M. and Manica, A. 2015. "Walk on the Wild Side: Estimating the Global Magnitude of Visits to Protected Areas." PLOS Biology, 13(2): e1002074. doi:10.1371/ journal.pbio. 1002074

Bhandari, K. 2012. Tourism or Conservation? A Controversy in Chitwan National Park,Nepal. In: O. Moufakkir and P. M. Burns (Eds.), Controversies in Tourism (pp. 229-241). CABI.

Brandon, K. 1998. Perils to Parks: The Social Context of Threats. In: K. Brandon, K.H. Redford and S.E. Sanderson (Eds.), Parks in Peril: People, Politics and Protected Areas (pp.415-439). Washington: Island Press, for the Nature Conservancy.

Carey, C., Dudley N. and Stolton S. 2000. Squandering Paradise? The Importance and Vulnerability of the World's Protected Areas. Gland, Switzerland: World Wildlife Fund.

CBD. 2008. Secretariat of the Convention on Biological Diversity. Protected Areas in Today's World: Their Values and Benefits for the Welfare of the Planet. Technical Series no. 36, i-vii + 96 pages, Montreal.

CBS. 2014. National Population and Housing Census 2011.Volume 6, NPHC2011. Government of Nepal, National Planning Commission Secretariat. Central bureau of Statistics, Government of Nepal.

CBS. 2002. Population Census (2001): National Report. Central Bureau of Statistics, Government of Nepal.

Chaudhary, R.P. 2001. Ecotourism: Bridge between Biodiversity Conservation and Development in Nepal. Proceedings of The International Symposium On The Himalayan Environments: Mountain Sciences And Ecotourism/Biodiversity, 2426 November 2000, Kathmandu, Nepal.

CIFOR. 2014. Factsheet on Forests, Food Security and Nutrition. The Center for International Forestry Research, Bogor, Indonesia. (http://www.cifor.org/publications/pdf files/factsheet/4876-factsheet.pdf accessē on 25 April, 2016)

Coad, L., Campbell, A., Miles, L. and Humphries, K. 2008. The Costs and Benefits of Forest Protected Areas for Local Livelihoods: A Review of the Current Literature. Working Paper. Cambridge, U.K: UNEP World Conservation Monitoring Centre. 
Dharmaratne, G.S., Yee Sang, F. and Walling, L.J. 2000. Tourism Potentials for Financing Protected Areas. Annals of Tourism Research, 27(3): 590-610.

Emerton, L. 2001. The Nature of Benefits and the Benefits of Nature: Why Wildlife Conservation has not Economically Benefited Communities in Africa. In: D. Hulme and M. Murphree (Eds.), African Wildlife and Livelihoods: The Promise and Performance of Community Conservation (pp. 208-226). London: James Currey.

Fernández-Baca, J.C. and Martin, A.S. 2007. Indigenous Peoples and Protected Areas Management. Innovations in Conservation Series, Parks in Peril Program. Arlington, VA, USA: The Nature Conservancy.

GoN/MoFSC. 2014.Nepal Biodiversity Strategy and Action Plan 2014-2020.Government of Nepal,Ministry of Forests and Soil Conservation,Kathmandu,Nepal.

Heinen, J.T. and Shrestha, S.K. 2006. Evolving Policies for Conservation: An Historical Profile of the Protected Area System of Nepal. Journal of Environmental Planning and Management, 49(1): 41-58.

Igoe, J. 2006. Measuring the Costs and Benefits of Conservation to Local Communities. Journal of Ecological Anthropology, 10: 7277

Karanth K.K. and Nepal S.K. 2012. Local Residents Perception of Benefits and Losses from Protected Areas in India and Nepal. Environmental Management, 49(2): 372-386.

Kareiva, P. and Marvier, M. 2007. Conservation for the People. Scientific American, 297: 5057.

Kruger, O. 2005. The Role Of Ecotourism In Conservation: Panacea or Pandora's Box? Biodiversity and Conservation, 14: 579-600.

Lipton, J.K. and Bhattarai, U. 2014. Park Establishment,Tourism, and Livelihood Changes: A Case Study of the Establishment of Chitwan National Park and the Tharu People of Nepal. American International Journal of Social Science, 3(1): 12-24.

McLean, J. 1999. Conservation and the Impact of Relocation on the Tharus of Chitwan,Nepal. Himalayan Research Bulletin, 38-44.

McNeely, J.A. and K.R. Miller (Eds.). 1984. National Parks, Conservation and Development: The Role of Protected Areas in Sustaining Society. Washington D.C.: Smithsonian Institute Press.
Meir, E., Andelman, S. and Possingham, H. P. 2004. Does Conservation Planning Matter in Dynamic and Uncertain World? Ecology Letters, 7(8): 615-622.

MoCTCA. 2014. Tourism Employment Survey. The Ministry of Culture Tourism and Civil Aviation, Government of Nepal.

Muller-Boker, U. 1999. The Chitwan Tharus in Southern Nepal: An Ethnoecological Approach. France: Franz Steiner Verlag Stuttgart.

Muller-Boker, U. 2000. State Intervention in Chitwan: On the Historical Development of a Region in Southern Nepal. Studies in Nepali History and Society, 5(2): 173-200.

Nepal, S.K. 2000. Tourism in Protected Areas: the Nepalese Himalaya. Annals of Tourism Research, 27(3):661-681.

Nepal, S.K. and K. E. Weber. 1993.Struggle for Existence: Park-people Conflict in the Royal Chitwan National Park, Nepal. Bangkok, Thailand: Asian Institute of Technology.

Nepal, S.K., 1997. Sustainable Tourism, Protected Areas and Livelihood Needs of Local Communities in Developing Countries. The International Journal of Sustainable Development and World Ecology, 4(2):123135.

Nyaupane G.P. and Poudel, S. 2014. Linkages among Biodiversity, Livelihood and Tourism. Annals of Tourism Research, 38(4): 1344-1366.

Nyaupane G.P. and Thapa, B. 2004. Evaluation of Ecotourism: A Comparative Assessment in the Annapurna Conservation Area Project, Nepal. Journal of Ecotourism, 3(1): 20-45.

ODI. 2014. Structural Economic Transformation in Nepal: A Diagnostic Study Submitted to DFID Nepal. U.K: Overseas Development Institute (https://www.odi.org/sites/ odi.org.uk/files/odi-assets/publicationsopinion-files/9019.pdf accessed on 1 April, 2016).

O'Riordan, T. and S. Stoll-Kleeman. 2002. Deliberative Democracy and Participatory Biodiver $\neg$ sity. In: T. O'Riordan and S. StollKleeman (Eds.), Biodiversity, Sustainability and Human Communities: Protecting Beyond the Pro $\neg$ tected (pp. 87-112). Cambridge: Cambridge University Press.

Pandey, R.N., Chettri, P. and Kunwar, R.R. 1995. Case Study on the Effects of Tourism 
on Culture and the Environment, Nepal: Chitwan-Sauraha and Pokhara-Ghandruk. Bangkok, Thailand: UNESCO.

Pandit R., Dhakal, M. and Maksym, P. 2015. Valuing Access to Protected Areas in Nepal: the Case of Chitwan National Park. Tourism Management, 50: 1-12. http://dx.doi. org/10.1016/j.tourman.2014.12.017

Paudel, N.S., Jana, S. and Khatiwada, B. 2012. Contestation and Citizen-Led Negotation around the Establishment of Protected Areas in Nepal Himalaya. Journal of Forest and Livelihood, 10(1): 42-57.

Paudel, N.S., Jana, S. and Rai, J. 2010. Protected Areas and Rights Movements: the Inadequacies of Nepal's Participatory Conservation. Discussion Paper Series 10.3. Kathmandu: Forest Action Nepal.

Paudel, N.S., Sudeep J. and Rai, J. 2010. Protected Area and Rights Movements: The Inadequacies of Nepal's Participatory Conservation. Discussion Paper Series 10.3. Kathmandu: ForestAction Nepal.

Rands M.R.W., Adams, W.M., Bennun, L., Butchart, S.H.M., Clements, A., Coomes, D., Entwistle, A., Hodge, I., Scharlemann, VK.J., Sunderland, W.J. and Vira, B. 2010. Biodiversity Conservation: Challenges Beyond 2010. Science, 329: 1298-1303.

Sharma, U.R. 1990. An Overview of Parkpeople Interactions in Royal Chitwan National Park, Nepal. Landscape and Urban Planning, 19(2):133-144.

Shrestha, U., Shrestha, S., Chaudhary, P. and Chaudhary, R.P. 2010. How Representative is the Protected Areas System of Nepal? A Gap Analysis Based on Geophysical and Biological Features. Mountain Research and Development, 30(3): 282-294. doi: http:// dx.doi.org/10.1659/MRD-JOURNAL-D10-00019.1

Spiteri, A. and Nepal, S.K. 2008. Distributing Conservation Incentives in the Buffer Zone of Chitwan National Park, Nepal. Environmental Conservation, 35(01): 76-86. doi:http://dx.doi.org/10.1017/ S0376892908004451
Stevens, S. 2013. National Parks and ICCAs in the High Himalayan Region of Nepal: challenges and opportunities. Conservation and Society, 11(1):29-45.

Suman, P. 2012. Marginalization of the Tharu Ethnic Group in Tourism Development in Nepal. TURIZAM, 16(2):40-49.

Sunam, R.K., Bishwokarma, D. and Darjee, K.B. 2015 . Conservation Policy Making in Nepal: Problematising the Politics of Civic Resistance. Conservation and Society, 13(2): 179-188.

Treves, L.N., Holland, M.B. and Brandon, K. 2005. The Role of Protected Areas in Conserving Biodiversity and Sustaining Local Livelihoods. Annual Review of Environmental Resources, 30: 219-252.

UNEP. 2003. Tourism and Biodiversity: Mapping Tourism's Global Footprint. Washington D.C.: United Nations Environment Program.

UNESCO. 1995. Case Study on the Effects of Tourism on Culture and the Environment. UNESCO Principal Regional Office for Asia and The Pacific. Bangkok, Thiland.

Vandergeest, P. 2003. Land to Some Tillers: Development-indused Displacement in Laos. International Social Science Journal, 55(175): 47-56.

Venter, O., Fuller, R.A., Segan, D.B., Carwardine, J., Brooks, T., Butchart, S.H.M., Di Marco, M., Iwamura, T., Joseph, L., O'Grady, D., Possingham, H.P., Rondinini, C., Smith, R.J., Venter, M. and Watson, J.E.M. 2014. Targeting Global Protected Area Expansion for Imperiled Biodiversity. PLoS Biology, 12(6), e1001891.

Watson, J.E., Dudley, N., Segan, D.B. and Hockings, M. 2014. The Performance and Potential of Protected Areas. Nature, 515: 67-73.

WTTC. 2015. Travel and Tourism Economic Impacts 2015, Nepal. Kathmandu: World Travel and Tourism Council. www.wttc. org 